\title{
Adaptation of Warli art for the development of blocks for printing of apparels
}

\author{
VEDIKA, EKTA GROVER AND SUSAN PAUL
}

Received: 08.04.2014; Revised: 22.09.2014; Accepted: 03.10.2014

See end of the paper for authors' affiliations

\section{VEDIKA}

Department of Textiles and Apparel Designing, Ethelind School of Home Science, Sam Higginbottom Institute of Agriculture, Technology and Sciences, ALLAHABAD (U.P.) INDIA

Email: aryavedika@gmail.com
ABSTRACT : India had always been known as the land that portrayed cultural and traditional vibrancy through its conventional arts and crafts. Every region in India has its own style and pattern of art, which is generally known as folk art. Perhaps the best-known genre of Indian folk paintings is the Warli painting from Maharashtra state. Traditionally Warli paintings were done by hand which is tedious, time consuming and laborious process. But due course of time with easy availability of different styles of printing, these paintings can be brought down on cloth by using various printing techniques. Hence, in the present study an attempt was made to develop blocks of Warli paintings of Maharashtra for printing of apparels and handicraft items. Total thirty designs were developed with the help of computer software "Adobe Photoshop" and "Corel Draw", ten each for apparels including kurties, suits and sarees. All the developed designs were subjected to visual evaluation for selection of two best designs from each category by the panel of thirty judges. The selected designs were applied on apparels using block printing technique. The cost of each article was calculated on the basis of expenditure on raw materials, labour charges, finishing charges and profit margin. Among the apparel items, brick red and black colour printed kurti (K9), green and purple colour painted suit (D7) and purple colour printed saree (S6) were highly appreciated and accepted. However, all the other products were also appreciated. Selling price of apparel items was ranged between Rs. 492/- to Rs. 1163/-. The adaptation of Warli motifs on apparels using block printing has paved the way for the plethora of product diversification that could lead to a flourishing market.

KEY WORDS: Warli art, Printing apparels

- HOW TO CITE THIS PAPER : Vedika, Grover, Ekta and Paul, Susan (2014). Adaptation of Warli art for the development of blocks for printing of apparels. Asian J. Home Sci., 9 (2) : 417-421. 